\title{
帯板要素と角柱要素を結合した鋼床版舗装 構造解析モデルの開発
}

\author{
西澤辰男 1 \\ ${ }^{1}$ 正会員 工博 石川工業高等専門学校助教授 環境都市工学科 ( $\bar{T}$ 929-0.392 河北郡津幡町北中条)
}

\begin{abstract}
鋼床版舗装の挙動は，鋼床版の構造や荷重の作用位置によって大きく影響を受けるため，鋼床版舗装の解析に は，これらの条件を正確に考慮できるものでなければならない，本研究においては，鋼床版舗装のひずみを予測 するための力学モデルを開発した。デッキブレートを帯板要素に，その上の舗装を角柱要素で表し，両者を特 殊な接着要素にて連結するものである．帯板要素はデッキプレートばかりでなく縦リブや腹板などの鋼床版の 複雑な構造を正確にモデル化できる。また，角柱要素は曲げ変形だけでなく，舗装自体の局部変形をも考慮す ることができる。しかしながら，この両者を結合する接着要素の定式化はやや複雑になる．開発したモデルの

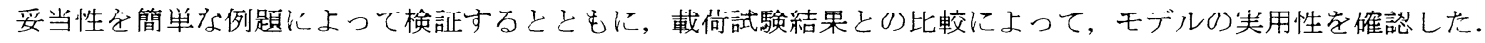

Key Words : pavement on steel plate deck, structural model, FSM, prizm element, strip element

\section{1.はじめに}

鋼床版はデッキプレートとそれを裏から補強する縦 リブ，横リブからなる橋梁の床版である. 鋼床版の上が グースアスファルトや改質アスファルトによって舗装 され，その上を交通車両が走行することになる。この ような鋼床版舗装に交通荷重が作用すると，縦リブや 腹版接合部には局部的な曲げ変形が生じ, それに追従 している舗装にも大きな曲げひずみが生ずることにな る 1),2). その結果, 比較的早期にこのような場所から 縦ひび割れが発生する。このような縌ひび割れを防止 する対策としては，あらかじめ縌ひび割れが発生する と予想される場所に目地を設置する方法がある. 適切 な目地の設置を設定するためには，設計段階において 少なくとも最大ひずみが生ずる位置を予測しなければ ならない，そのために，鋼床版舗装の力学モデルが必 要となる。

鋼床版の構造や交通荷重の作用位置の微妙な組み合わ せによって鋼床版舗装の挙動が大きく異なるため3),4),5)， 縦ひび割れの発生位置は, 縦リブや箱桁腹版などの配 置に大きく影響される。したがって, 鋼床版舗装の解析 においては，鋼床版の構造と交通荷重を同時に考慮し なくてはならない.このような解析手法の 1 つとして， 有限帯板要素法 (Finite Strip Method: FSM) によるも のがある.この手法においては，デッキプレートとアス ファルト混合物層（以下，アスファルト層）から成る複 合平板として取り扱う方法が取られている6),7)。しか しながら，この方法では，アスファルト層にのみ設置 されている縦目地の効果や，アスファルト層の厚さ方
向の変形を考慮することができない。そこで，これら の問題を克服するために帯板要素をオーバーレイする モデル (Overlaid Finite Strip Method: OFSM) が開発 された ${ }^{8)}$.このモデルによれば，舗装の厚さ方向の変 形や縦目地も考慮することができる。しかし OFSM で は舗装自体の挙動を曲げ変形で表現するために, 舗装 自体の (特に高温時の) 局部的な変形を細かく考慮でき ない，特に舗装自体の剛性が低くなると，タイヤ端部 に大きなひずみが発生することが知られており9)，こ の上うな局部変形を解析する必要がある。そこで，本 研究においては舗装の局部的な変形を考慮できる角柱 要素と帯板要素を結合したモデルを開発することとし た．本論文では，前半部において両要素を結合する接 着要素を中心に FEM への定式化について述べ，後半部 では簡単な例題および実験結果との比較によりモデル の妥当性を検証している.

\section{2. 構造モデル}

本研究で開発した帯板要素 (Strip element) と角柱要 素 (Prism element) を接着要素 (Link element) で結合 したモデルを図-1に示寸。これを，SLPE(Strip-LinkPrism Element) モデルと呼ぶことにする. 帯板要素は, 平板の曲げ変形をモデル化した要素であり, デッキブ レート，縦リブを含む鋼床版全体の構造を細かく考慮 寸ることが可能である。 また，角柱要素忙舗装を代表 し，8節点の要素なので，厚さ方向の変形を含む局部的 な変形を表現することができる，接着要素は，帯板要 素と角柱要素を接合寸る役割を持ち，ちょうどデッキ 


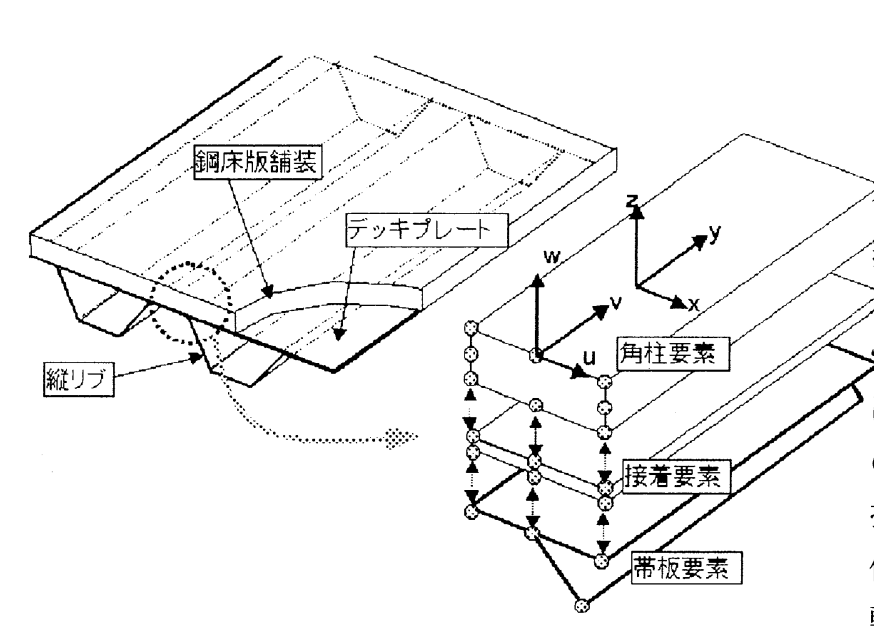

図-1 鋼床版舗装解析のための SLPE モデル

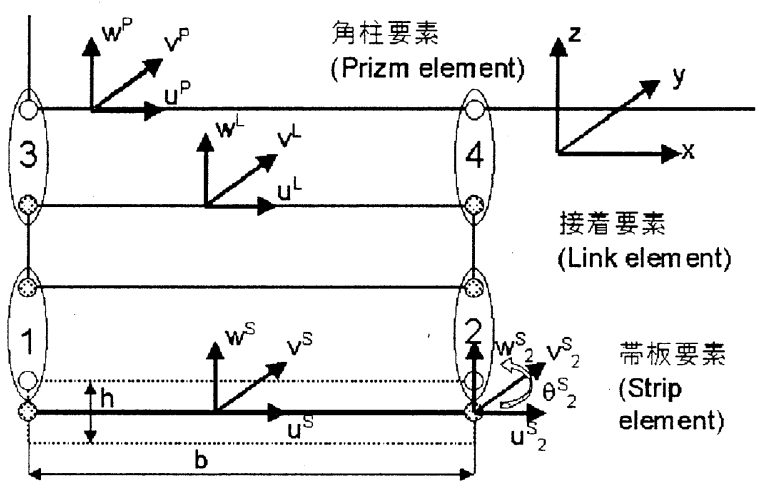

図-2 帯板要素, 角柱要素および接着要素の自由度

プレートと舗装の間に施される接着層の機能をモデル 化することになる．たたし，带板要素と角柱要素で採 用する節点自由度 (変位) が異なるため, それらを結合 するためには特殊な要素を新たに開発しなければなら ない.

\section{3. 接着要素の定式化}

本章においては接着要素の定式化の過程を述べる.そ のためには，まず帯板要素と角柱要素の変位関数につ いても触れておが衫ばならない，図-2 は，帯板要素と 角柱要素を接着要素が結合した状態を表したものであ る. それぞれの要素内の変位もまとめて表示している.

これらの要素は, $x, z$ 面内で通常の FEM と同様に 要素分割されて節点を持ち, その節点での自由度と適 切な内挿関数を用いて内部の変位を記述する. 一方, $y$ 方向の変位はフーリエ級数に展開して表現し，その振 幅が節点变位となる，本研究においては，鋼床版の横 桁間を解析対象とし，そのスパンをlで表す. $y$ 方向の 境界条件としては， $y=0, y=l$ において $x, z$ 面内 の変位はゼロと仮定し，その境界条件を満足するフー
リエ三角級数に展開した.

接着要素と角柱要素とは節点 3,4 が共有されており, この部分で結合されている．接着要素と帯板要素の結 合には注意が必要である，なぜなら，奉際には接着要 素以帯板要素の表面と結合しなければならないが, 帯 板要素は厚さ方向の次元を持たないため, 直接節点 1 , 2 を共有させると, 帯板要素の中立面と結合すること になるからである. そこで, 図に示すように带板要素 の表面に相当寸る位置に仮の節点を設け，この節点と 接着要素の節点を共有させておく，帯板要素の節点変 位とその表面の仮の節点変位は，帯板要素の厚さと回 転変位を利用して関係づける。最初, 接着要素の剛性 マトリックスは 1,2 仮想節点之 3,4 節点の変位を用 いて導いておき，上述した考え方で，帯板要素の節点 変位と関係づけられた剛性マトリックスを導く。こう して導かれた接着要素の剛性マトリックスは, 節点に よって 3 個と 4 個の自由度が混在した特殊なものとな る. 以下具体的に定式化していく.

\section{(1) 帯板要素 (Strip element)}

帯板要素は幅 $b$, 厚さ $h$ の曲げ要素で, 両端に節点を 持つ. それぞれの節点は 3 方向の変位に加え, $y$ 軸周り の回転変位を持つ. 節点変位を用いると, 要素内部の 変位は以下のように表される。

$$
\left\{\begin{array}{c}
u^{S} \\
v^{S} \\
w^{S}
\end{array}\right\}=\sum_{m=1}^{M} \sum_{i=1}^{2}
$$$$
\left[\begin{array}{cccc}
N_{1 i}^{S} \cdot s_{m} & 0 & 0 & 0 \\
0 & N_{1 i}^{S} \cdot c_{m} & 0 & 0 \\
0 & 0 & N_{2 i}^{S} \cdot s_{m} & N_{3 i}^{S} \cdot s_{m}
\end{array}\right] \cdot\left\{\begin{array}{c}
u_{i m}^{S} \\
v_{i m}^{S} \\
w_{i m}^{S} \\
\theta_{i m}^{S}
\end{array}\right\}
$$

\section{ここにー}

$$
\begin{aligned}
& u^{S}, v^{S}, w^{S}=\text { 帯板要素内の } x, y, z \text { 方向の変位, } \\
& N_{11}^{S}=\left(1-\frac{x}{b}\right), N_{12}^{S}=\frac{x}{b}, \\
& N_{21}^{S}=1-\frac{3 x^{2}}{b^{2}}+\frac{2 x^{3}}{b^{3}}, N_{22}^{S}=\frac{3 x^{2}}{b^{2}}, \\
& N_{31}^{S}=x\left(1-\frac{2 x}{b}+\frac{x^{2}}{b^{2}}\right), N_{32}^{S}=x\left(-\frac{x}{b}+\frac{x^{2}}{b^{2}}\right), \\
& s_{m}=\sin \left(\gamma_{m} y\right), c_{m}=\cos \left(\gamma_{m} y\right), \gamma_{m}=\frac{m \pi}{l} \\
& u_{i m}^{S}, v_{i m}^{S}, v_{i m}^{S}=m \text { モードにおける } i \text { 節点の変位, } \\
& \theta_{i m}=\left[\frac{\partial w_{m}^{S}}{\partial x}\right]_{i}
\end{aligned}
$$

$m$ はフーリエ級数のモードを表し， $M$ は採用寸る項数 である.この変位関数に基づいて帯板要素の剛性マト リックスが導かれる 12),13). 
(2) 角柱要素 (Prism element)

角柱要素は 8 個の節点を持ち, それぞれの節点の自 由度は 3 方向の変位である. それらの節点変位を用い て, 要素内部の変位注以下のように表される.

$$
\begin{aligned}
& \left\{\begin{array}{c}
u^{P} \\
v^{P} \\
w^{P}
\end{array}\right\}=\sum_{m=1}^{M} \sum_{i=1}^{8} \\
& {\left[\begin{array}{ccc}
N_{i}^{P} \cdot s_{m} & 0 & 0 \\
0 & N_{i}^{P} \cdot c_{m} & 0 \\
0 & 0 & N_{i}^{P} \cdot s_{m}
\end{array}\right] \cdot\left\{\begin{array}{c}
u_{i m}^{P} \\
v_{i m}^{P} \\
w_{i m}^{P}
\end{array}\right\}}
\end{aligned}
$$

ここに,

$u^{P}, v^{P}, w^{P}=$ 角柱要素内の $x, y, z$ 方向の変位, $u_{i m}^{P}, v_{i m}^{P}, v_{i m}^{P}=m$ モードにおける $i$ 節点の変位,

また, $N_{i}^{P}(\mathrm{i}=1,8)$ は, 8 節点要素の変位関数である. この変位関数に基づいて角柱要素の剛性マトリックス が作成される ${ }^{14)}$.

\section{(3) 接着要素 (Link element)}

接着要素は厚さが 0 で 4 個の節点を持ち，それぞれ の節点は带板要素の表面と角柱要素の節点と結合して いる. 内部の変位は, 帯板要素に接している辺 $[1-2]$ と 角柱要素に接している辺 [3-4] に対して別々に定義され る. まず，帯板要素の表面と接寸る辺 [1-2]においては,

$$
\begin{aligned}
& \left\{\begin{array}{c}
u^{L} \\
v^{L} \\
w^{L}
\end{array}\right\}_{[1-2]}=\sum_{m=1}^{M} \sum_{i=1}^{2} \\
& {\left[\begin{array}{ccc}
N_{1 i}^{S} \cdot s_{m} & 0 & 0 \\
0 & N_{1 i}^{S} \cdot c_{m} & 0 \\
0 & 0 & N_{1 i}^{S} \cdot s_{m}
\end{array}\right] \cdot\left\{\begin{array}{c}
u_{i m}^{L} \\
v_{i m}^{L} \\
w_{i m}^{L}
\end{array}\right\}}
\end{aligned}
$$

ここに,

$u^{L}, v^{L}, w^{L}=$ 接着要素内の $x, y, z$ 方向の変位, $u_{i m}^{L}, v_{i m}^{L}, v_{i m}^{L}=m$ モードにおける $i$ 節点の変位,

また，角柱要素し接する辺 [3-4]に拀いては，

$$
\begin{aligned}
& \left\{\begin{array}{c}
u^{L} \\
v^{L} \\
w^{L}
\end{array}\right\}_{[3-4]}=\sum_{m=1}^{M} \sum_{i=3}^{4} \\
& {\left[\begin{array}{ccc}
N_{1(i-2)}^{S} \cdot s_{m} & 0 & 0 \\
0 & N_{1(i-2)}^{S} \cdot c_{m} & 0 \\
0 & 0 & N_{1(i-2)}^{S} \cdot s_{m}
\end{array}\right] \cdot\left\{\begin{array}{c}
u_{i m}^{L} \\
v_{i m}^{L} \\
w_{i m}^{L}
\end{array}\right\}}
\end{aligned}
$$

$N_{1 i}^{S}$ は式 (1) と同じ 1 次関数である. 帯板要素の変位関 数は 3 次なので, 厳密に言うと節点変位を共有しても
帯板要素の変位と辺 [1-2] の変位との適合条件は満足さ れていないことになる。 しかしながら，後の数值計算 例からわかるように，このような不適合が存在しても 適切な要素分割を行えば，実用的には十分な精度を得 ることが可能である.

\section{（4）接着要素の剛性マトリックス}

接着要素では, 帯板要素に接する辺 [1-2] の変位と角 柱要素に接寸る辺 [3-4] の変位の差に比例した力が伝達 されると仮定する.すなわち,

$$
\begin{gathered}
\left\{\begin{array}{l}
\Delta f_{x}^{L} \\
\Delta f_{y}^{L} \\
\Delta f_{z}^{L} \\
\Delta f_{\theta x}^{L} \\
\Delta f_{\theta y}^{L}
\end{array}\right\}=\left[\begin{array}{ccccc}
k_{x}^{L} & 0 & 0 & 0 & 0 \\
0 & k_{y}^{L} & 0 & 0 & 0 \\
0 & 0 & k_{z}^{L} & 0 & 0 \\
0 & 0 & 0 & k_{\theta x}^{L} & 0 \\
0 & 0 & 0 & 0 & k_{\theta y}^{L}
\end{array}\right] \cdot\left\{\begin{array}{c}
\Delta u^{L} \\
\Delta v^{L} \\
\Delta w^{L} \\
\Delta \theta_{x}^{L} \\
\Delta \theta_{y}^{L}
\end{array}\right\} \\
\left\{\Delta f^{L}\right\}=\left[\mathbf{K}^{L}\right]\left\{\Delta \delta^{L}\right\}
\end{gathered}
$$

ここに,

$$
\begin{aligned}
& k_{x}^{L}, k_{y}^{L}, k_{z}^{L}=x, y, z \text { 方向のばね係数 } \\
& k_{\theta x}^{L}, k_{\theta y}^{L}=x, y \text { 軸周りの回転ばね係数 } \\
& \theta_{x}=\frac{\partial w}{\partial y}, \theta_{y}=\frac{\partial w}{\partial x}
\end{aligned}
$$

である，一方， $\Delta$ は辺 [1-2] と辺 [3-4] の諸量の差である ことを表す。

それぞれの辺に沿った回転を含む変位は以下のよう になる. 辺 [1-2]において，式(3)より，

$$
\left\{\begin{array}{c}
u^{L} \\
v^{L} \\
w^{L} \\
\theta_{x}^{L} \\
\theta_{y}^{L}
\end{array}\right\}_{[1-2]}=\sum_{m=1}^{M} \sum_{i=1}^{2}
$$

$$
\left[\begin{array}{ccc}
N_{1 i}^{S} \cdot s_{m} & 0 & 0 \\
0 & N_{1 i}^{S} \cdot c_{m} & 0 \\
0 & 0 & N_{1 i}^{S} \cdot s_{m} \\
0 & N_{1 i}^{S} \cdot \gamma_{m} \cdot c_{m} & 0 \\
0 & \frac{\partial N_{1 i}^{S}}{\partial x} \cdot s_{m} & 0
\end{array}\right] \cdot\left\{\begin{array}{c}
u_{i m}^{L} \\
v_{i m}^{L} \\
w_{i m}^{L}
\end{array}\right\}
$$

$$
=\sum_{m=1}^{M} \sum_{i=1}^{2}\left[\mathbf{N}_{1 i m}^{L}\right]\left\{\delta_{i m}^{L}\right\}
$$


また，辺 [3-4]において，式(4)より，

$\left\{\begin{array}{l}u^{L} \\ v^{L} \\ w^{L} \\ \theta_{x}^{L} \\ \theta_{y}^{L}\end{array}\right\}=\sum_{m=1}^{M} \sum_{i=3}^{4}$

$\left[\begin{array}{ccc}N_{1(i-2)}^{S} \cdot s_{m} & 0 & 0 \\ 0 & N_{1(i-2)}^{S} \cdot c_{m} & 0 \\ 0 & 0 & N_{1(i-2)}^{S} \cdot s_{m} \\ 0 & N_{1(i-2)}^{S} \cdot \gamma_{m} \cdot c_{m} & 0 \\ 0 & \frac{\partial N_{1(i-2)}^{S} \cdot s_{m}}{\partial x} \cdot 0\end{array}\right] \cdot\left\{\begin{array}{c}u_{i m}^{L} \\ v_{i m}^{L} \\ w_{i m}^{L}\end{array}\right\}$

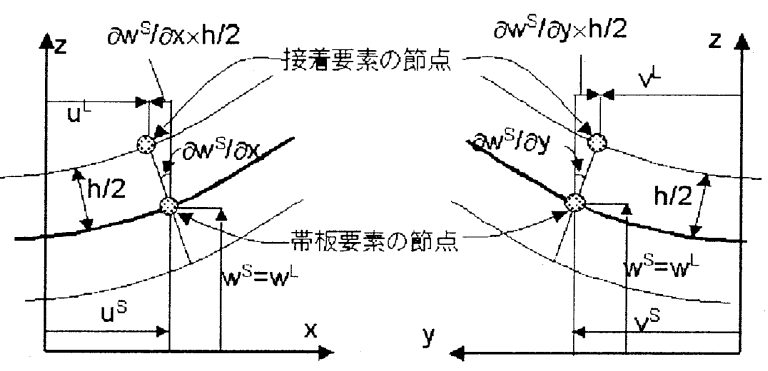

図-3 帯板要素と接着要素の節点変位の関係

はならない，接着要素は帯板要素の表面で結合してい ると仮定すると, 図-3に示寸ように接着要素と帯板要 素の節点の変位間には以下のような関係がある.

したがって, 変位の差は,

$$
\begin{aligned}
& \left\{\begin{array}{l}
\Delta u^{L} \\
\Delta v^{L} \\
\Delta w^{L} \\
\Delta \theta_{x}^{L} \\
\Delta \theta_{y}^{L}
\end{array}\right\}=\left\{\begin{array}{l}
u^{L} \\
v^{L} \\
w^{L} \\
\theta_{x}^{L} \\
\theta_{y}^{L}
\end{array}\right\}_{[1-2]}-\left\{\begin{array}{l}
u^{L} \\
v^{L} \\
w^{L} \\
\theta_{x}^{L} \\
\theta_{y}^{L}
\end{array}\right\}_{[3-4]} \\
& =\sum_{m=1}^{M}\left[\begin{array}{llll}
\mathbf{N}_{11 m}^{L} & \mathbf{N}_{12 m}^{L} & -\mathbf{N}_{11 m}^{L} & -\mathbf{N}_{12 m}^{L}
\end{array}\right]\left\{\begin{array}{l}
\delta_{1 m}^{L} \\
\delta_{2 m}^{L} \\
\delta_{3 m}^{L} \\
\delta_{4 m}^{L}
\end{array}\right\}
\end{aligned}
$$

$$
\begin{aligned}
u_{i}^{L} & =u_{i}^{S}-\left[\frac{\partial w^{S}}{\partial x}\right]_{i} \cdot \frac{h}{2} \\
v_{i}^{L} & =v_{i}^{S}-\left[\frac{\partial w^{S}}{\partial y}\right]_{i} \cdot \frac{h}{2} \\
w_{i}^{L} & =w_{i}^{S}
\end{aligned}
$$

上式に式 (1) を代入してモードごとに表せば次のよう になる。

となる。これらを用いて, 仮想仕事の原理より, 次式 のような剛性方程式が得られる:

$$
\left\{\begin{array}{l}
f_{1 m}^{L} \\
f_{2 m}^{L} \\
f_{3 m}^{L} \\
f_{4 m}^{L}
\end{array}\right\}=\left[\begin{array}{cccc}
\mathbf{K}_{11 m}^{L} & \mathbf{K}_{12 m}^{L} & -\mathbf{K}_{11 m}^{L} & -\mathbf{K}_{12 m}^{L} \\
* & \mathbf{K}_{22 m}^{L} & -\mathbf{K}_{12 m}^{L T} & -\mathbf{K}_{22 m}^{L} \\
* & * & \mathbf{K}_{11 m}^{L} & \mathbf{K}_{12 m}^{L} \\
* & * & * & \mathbf{K}_{22 m}^{L}
\end{array}\right]\left\{\begin{array}{l}
\delta_{1 m}^{L} \\
\delta_{2 m}^{L} \\
\delta_{3 m}^{L} \\
\delta_{4 m}^{L}
\end{array}\right\}
$$

ここに,

$$
\begin{aligned}
& \mathbf{K}_{11 m}^{L}=\frac{l}{2} \int_{0}^{b} \mathbf{N}_{11 m}^{L T} \mathbf{K}^{L} \mathbf{N}_{11 m}^{L} d x \\
& \mathbf{K}_{12 m}^{L}=\frac{l}{2} \int_{0}^{b} \mathbf{N}_{11 m}^{L T} \mathbf{K}^{L} \mathbf{N}_{12 m}^{L} d x \\
& \mathbf{K}_{22 m}^{L}=\frac{l}{2} \int_{0}^{b} \mathbf{N}_{12 m}^{L T} \mathbf{K}^{L} \mathbf{N}_{12 m}^{L} d x
\end{aligned}
$$

また，剛性マトリックスの*は対角要素に対して対称で あることを示す。

\section{（5）各要素の節点と接着要素の節点の結合}

式 (9) は帯板要素の表面の仮想節点に対するものな ので，改めて実際の帯板要素の節点と関係づけなくて
一方, 接着要素と角柱要素の節点の自由度は同じで あるから，

$$
\begin{aligned}
\left\{\begin{array}{c}
u_{i m}^{L} \\
v_{i m}^{L} \\
w_{i m}^{L}
\end{array}\right\} & =\left[\begin{array}{lll}
1 & 0 & 0 \\
0 & 1 & 0 \\
0 & 0 & 1
\end{array}\right]\left\{\begin{array}{c}
u_{i m}^{P} \\
v_{i m}^{P} \\
w_{i m}^{P}
\end{array}\right\} \\
\left\{\delta_{i m}^{L}\right\} & =[\mathbf{I}]\left\{\delta_{i m}^{P}\right\} \quad(i=3,4)
\end{aligned}
$$

$$
\begin{aligned}
u_{i m}^{L} & =u_{i m}^{S}-\theta_{i m}^{S} \cdot \frac{h}{2} \\
v_{i m}^{L} & =v_{i m}^{S}-\frac{h \gamma_{m}}{2} \cdot w_{i m}^{S} \\
w_{i m}^{L} & =w_{i m}^{S}
\end{aligned}
$$

これらをマトリックス表示すれば次式となる。

$\left\{\begin{array}{c}u_{i m}^{L} \\ v_{i m}^{L} \\ w_{i m}^{L}\end{array}\right\}=\left[\begin{array}{cccc}1 & 0 & 0 & -\frac{h}{2} \\ 0 & 1 & -\frac{h}{2} \gamma_{m} & 0 \\ 0 & 0 & 1 & 0\end{array}\right]\left\{\begin{array}{c}u_{i m}^{S} \\ v_{i m}^{S} \\ w_{i m}^{S} \\ \theta_{i m}^{S}\end{array}\right\}$

$\left\{\delta_{i m}^{L}\right\}=\left[\mathbf{R}_{m}\right]\left\{\delta_{i m}^{S}\right\} \quad(i=1,2)$

ここに，[I]は単位マトリックスである. 


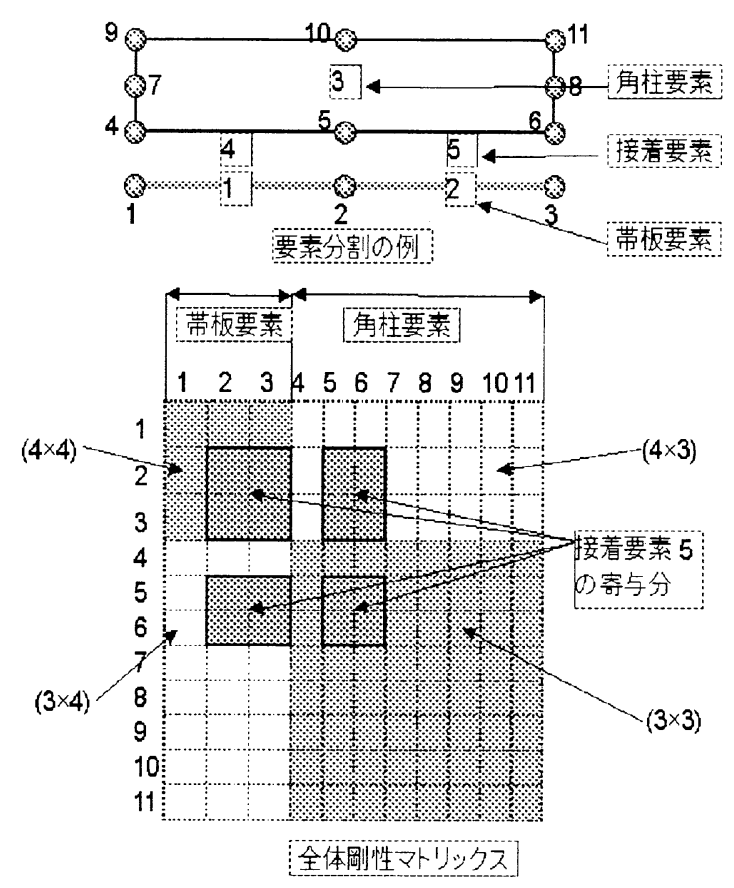

図-4 全体剛性マトリックスのデータ構造

\section{（6）接着要素の剛性マトリックス}

式 (11) と式 (13) を式 (9) に代入して整理すると, 次 式のような接着要素の剛性方程式が得られる.

$$
\begin{aligned}
& \left\{\begin{array}{c}
f_{1 m}^{S} \\
f_{2 m}^{S} \\
f_{3 m}^{P} \\
f_{4 m}^{P}
\end{array}\right\}=\left[\begin{array}{cc}
\mathbf{R}_{m}^{T} \mathbf{K}_{11 m}^{L} \mathbf{R}_{m} & \mathbf{R}_{m}^{T} \mathbf{K}_{12 m}^{L} \mathbf{R}_{m} \\
* & \mathbf{R}_{m}^{T} \mathbf{K}_{22 m}^{L} \mathbf{R}_{m} \\
* & * \\
* & *
\end{array}\right. \\
& \left.\begin{array}{cc}
-\mathbf{K}_{11 m}^{L} \mathbf{R}_{m} & -\mathbf{K}_{12 m}^{L} \mathbf{R}_{m} \\
-\mathbf{K}_{12 m}^{L T} \mathbf{R}_{m} & -\mathbf{K}_{22 m}^{L} \mathbf{R}_{m} \\
\mathbf{K}_{11 m}^{L} & \mathbf{K}_{12 m}^{L} \\
* & \mathbf{K}_{22 m}^{L}
\end{array}\right]\left\{\begin{array}{c}
\delta_{1 m}^{S} \\
\delta_{2 m}^{S} \\
\delta_{3 m}^{P} \\
\delta_{4 m}^{P}
\end{array}\right\}
\end{aligned}
$$

帯板要素, 角柱要素および接着要素からなる SLPE モデルのプログラムにおいては，4自由度の節点と 3 自 由度の節点が混在したマトリックスを取り扱うため, べ クトルやマトリックスのデータ構造には特別な注意が 必要である。

本研究で開発したプログラムにおいては, 要素番号 や節点番号を帯板要素と角柱要素で完全に分けて割り 振る.すなわち図-4 に示す構造を例にとると，節点 1 から 3 までは帯板要素の節点とし，4 から 11 までは角 柱要素の節点とする. 寸ると, 全体剛性マトリックス の前半部は帯板要素の部分, 後半部は角柱要素の部分 に分けられる．接着要素はこれらにまたがって配置さ れ，両者の力のやり取りを表現することになる．こう することによって, 要素剛性マトリックスの全体剛性

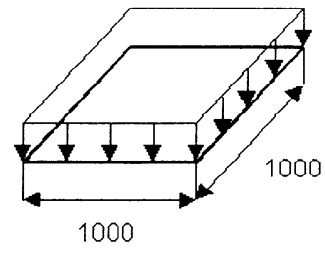

全体図
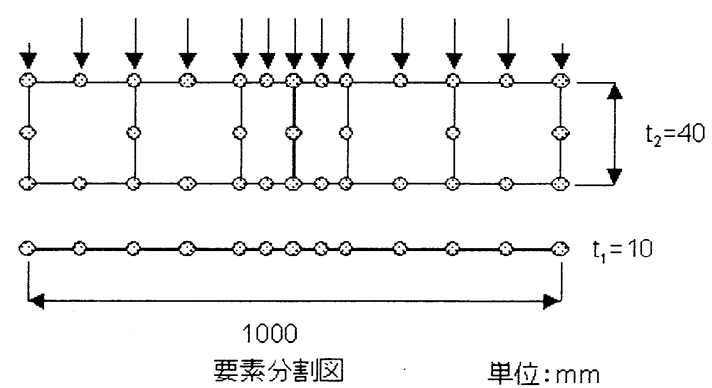

図-5 例題 1 の要素分割

表-1 例題 1 の計算結果. 平板中央部のひずみ分布 $\left(10^{-6}\right)$

\begin{tabular}{l|c|rrrr}
\hline \hline ID & 深さ $(\mathrm{mm})$ & 0 & -40 & -40 & -50 \\
\hline OLU & $\epsilon_{x}$ & -131.4 & 131.4 & -32.9 & 32.9 \\
& $\epsilon_{y}$ & -130.7 & 130.6 & -32.7 & 32.7 \\
\hline OLB & $\epsilon_{x}$ & -85.4 & 51.2 & 51.2 & 85.4 \\
& $\epsilon_{y}$ & -84.8 & 50.9 & 50.2 & 84.9 \\
\hline SL & $\epsilon_{x}$ & -85.2 & 51.1 & 51.1 & 85.2 \\
& $\epsilon_{y}$ & -84.9 & 50.9 & 50.9 & 84.9 \\
\hline SP1 & $\epsilon_{x}$ & -132.1 & 132.3 & -33.4 & 33.4 \\
& $\epsilon_{y}$ & -130.4 & 130.5 & -32.6 & 32.4 \\
\hline SP2 & $\epsilon_{x}$ & -132.0 & 132.2 & -32.9 & 33.4 \\
& $\epsilon_{y}$ & -130.2 & 130.4 & -32.7 & 32.3 \\
\hline SP3 & $\epsilon_{x}$ & -84.9 & 51.1 & 49.5 & 85.8 \\
& $\epsilon_{y}$ & -86.3 & 51.5 & 51.4 & 86.3 \\
\hline SP4 & $\epsilon_{x}$ & -85.3 & 51.4 & 49.7 & 86.2 \\
& $\epsilon_{y}$ & -86.6 & 51.7 & 51.3 & 86.6 \\
\hline \hline
\end{tabular}

マトリックスへの重ね合わせのルーチンが統一化され， データの取り扱いが容易になるのである.

\section{4. 例題による検証}

本章では, 開発したプログラムの妥当性を検討する ために，いくつかの構造について，本モデルによる解 析結果と，すでに有効性が実証されている OFSM モデ ルによる解析結果を比較する.

\section{(1) 例題 1:4 辺が単純支持された平板}

図-5に示吉上うに，4辺単純支持された正方形平板 に等分布荷重が作用している場合を考える. 平板の弾性 
係数は $1 \times 10^{4} \mathrm{MPa}$, ポアソン比は 0.2 , 荷重強度は 0.05 $\mathrm{MPa}$ とした．モデルとしては以下のものを考える.

・ OLU: $4 \mathrm{~cm}$ と $1 \mathrm{~cm}$ の 2 層 OFSM モデルで境界面 はアンボンド.

・ OLB: $4 \mathrm{~cm}$ と $1 \mathrm{~cm} の 2$ 層 OFSM モデルで境界面 はボンド.

- SL:5cm の 1 層 FSM モデル.

- SP1:4cm のプリズム要素と $1 \mathrm{~cm}$ の帯板要素で, 境 界面のばね $k_{x}^{L}=k_{y}^{L}=k_{\theta x}^{L}=k_{\theta y}^{L}=0, k_{z}^{L}=1 \times 10^{3}$.

- $\mathbf{S P 2}: 4 \mathrm{~cm}$ のプリズム要素と $1 \mathrm{~cm}$ の帯板要素で, 境 界面のばね $k_{x}^{L}=k_{y}^{L}=k_{\theta x}^{L}=k_{\theta y}^{L}=0, k_{z}^{L}=1 \times 10^{4}$.

- SP3:4cm のプリズム要素と $1 \mathrm{~cm}$ の帯板要素で, 境 界面のばね $k_{x}^{L}=k_{y}^{L}=k_{z}^{L}=1 \times 10^{4}, k_{\theta x}^{L}=k_{\theta y}^{L}=0$.

- SP4:4cm のプリズム要素と $1 \mathrm{~cm}$ の帯板要素で, 境界面のばね $k_{x}^{L}=k_{y}^{L}=k_{z}^{L}=1 \times 10^{4}, k_{\theta x}^{L}=k_{\theta y}^{L}=$ $1 \times 10^{3}$.

なお，ばね係数の值は単位長さあたりのものでその単 位は, $k_{x}^{L}, k_{y}^{L}, k_{z}^{L}$ に対して $\mathrm{MN} / \mathrm{m} / \mathrm{m}, k_{\theta x}^{L}, k_{\theta y}^{L}$ に対 しては $\mathrm{MN} / \mathrm{m}$ である. また，これらの值は，接着条件 がボンドとなるようにあらかじめ予備計算によって選 定されたものである. 表-1 は平板中央部の厚さ方向の ひずみ分布をまとめたものである．表の 1 行目は平板 表面からの深さ $(\mathrm{mm})$ であり, $-40 \mathrm{~mm}$ は 1 層目と 2 層 目の境界面になる. 2 列めの $\epsilon_{x}$ と $\epsilon_{y}$ はそれぞれ $\mathrm{x}, \mathrm{y}$ 方 向のひずみである. 構造, 荷重条件が $x, y$ 軸に対称で あるため, 本来 $\epsilon_{x}=\epsilon_{y}$ であるが, SLPE モデルの計算結 果には $1.6 \mu$ 程度の誤差が見られる. 境界面がアンボ ンドであれば，1 層と 2 層のそれぞれの中央面が中立面 となるため, 深さ $0 \mathrm{~mm}$ と- $40 \mathrm{~mm}$, および- $40 \mathrm{~mm}$ と $-50 \mathrm{~mm}$ のひずみの值は等しく符号が反対になる。一 方，ボンドであれば，2 層が一体となって中立面が 2 層 あわせた厚さの中央面に形成され， $0 \mathrm{~mm}$ と $-50 \mathrm{~mm}$ の ひずみ量は等しく符号は反対になる。また， 1 層目の底 面と 2 層目の表面である $-40 \mathrm{~mm}$ では，両方の層のひず み量等しくなる.この表より, OLU, SP1, SP2の ケースでは，境界面がボンドのひずみ分布を示し，そ れらケースの間での值がほぼ等しくなっている。一方,

OLB，SL，SP3，SP4のケースのひずみ分布は，境 界面がボンド条件のそれであることが分かる. 以上の結 果より，境界面の条件ごとに, SLPE モデルは OFSM モデルと同じ計算結果を与えることが確認された．ま た，SLPE は境界面のば敉定数を調整することにより， ボンド，アンボンドを表現できることが分かる.

\section{(2) 例題 2：U 型の縦リブを有する鋼床版上の舗装}

図-6 に示寸ような，1つの U 型縌リブを有する鋼 床版舗装のスパン中央に等分布荷重が作用するする場 合を考える. デッキプレートの弾性係数, ポアソン比,

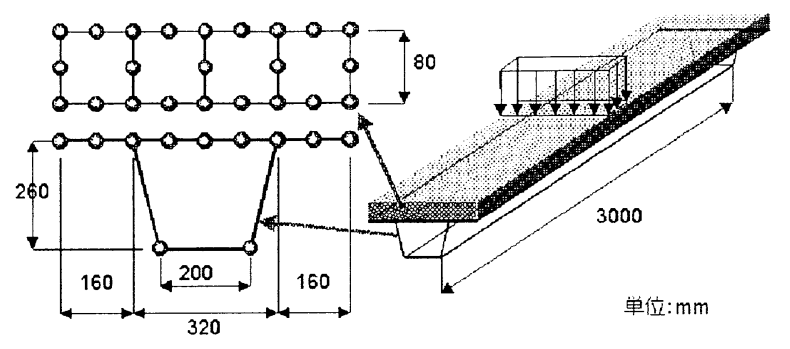

図-6 例題 2 の要素分割

表-2 例題 2 の計算結果. 荷重直下のひずみ分布 $\left(10^{-6}\right)$

\begin{tabular}{l|c|rrrr}
\hline \hline ID & 深さ $(\mathrm{mm})$ & 0 & -80 & -80 & -92 \\
\hline \multirow{2}{*}{ OLU } & $\epsilon_{x}$ & -8.5 & 75.6 & -29.2 & 38.0 \\
& $\epsilon_{y}$ & -256.6 & 78.3 & -144.4 & -64.0 \\
\hline \multirow{2}{*}{ OLB } & $\epsilon_{x}$ & 51.6 & 31.5 & 32.2 & 27.9 \\
& $\epsilon_{y}$ & -308.9 & -69.5 & -69.4 & -33.5 \\
\hline \multirow{2}{*}{ SP1 } & $\epsilon_{x}$ & -38.9 & 18.4 & 48.8 & 34.8 \\
& $\epsilon_{y}$ & -159.9 & 192.9 & -144.2 & -84.8 \\
\hline \multirow{2}{*}{ SP2 } & $\epsilon_{x}$ & 39.5 & 28.0 & 28.3 & 25.0 \\
& $\epsilon_{y}$ & -282.7 & -71.4 & -73.5 & -31.1 \\
\hline \hline
\end{tabular}

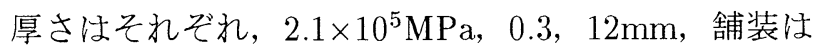
$1.0 \times 10^{4} \mathrm{MPa} ， 0.35,80 \mathrm{~mm}$ とした. なお，U型縌リブ の板厚は $6 \mathrm{~mm}$ とした. SLPE モデルとしては, 図-6に 示寸上うな要素分割を考え, 以下のケースを比較した.

・OLU：OFSM で境界面はアンボンド.

・OLB : OFSM で境界面はボンド.

-SP1 : SLPE モデルで, $k_{x}^{L}=k_{y}^{L}=k_{\theta x}^{L}=k_{\theta y}^{L}=0$, $k_{z}^{L}=1 \times 10^{4}$.

-SP2 : SLPE モデルで, $k_{x}^{L}=k_{y}^{L}=k_{z}^{L}=1 \times 10^{4}$, $k_{\theta x}^{L}=k_{\theta y}^{L}=1 \times 10^{4}$.

表-2 は荷重中心におけるひずみの計算結果である. 表の見方は表-1 と同様である.この場合, アンボンド 条件である OLU と SP1 では舗装内のひずタがかなり 異なる.これは舗装の厚さが厚いため, 局部的な変形が 顕著に表れたためである. ボンド条件である OLB と SP2の間でもアスファルト層のひずみはかなり異なる. このように, 舗装が厚い場合には, 曲げ変形では考慮で きない舗装内の局部的な変形が無視できなくなる．た だし，SP2において，アスファルト層底面とデッキプ レート表面のひずみ量はほぼ等しく, ボンド条件を満 足していると考えてよい.

\section{5. 実橋における載荷試験による検証 ${ }^{8)}$}

\section{（1）載荷試験概要}

本実験は神奈川県の湘南銀河大橋 (3 径間連続鋼斜張 橋) で実施された。厚さ $12 \mathrm{~mm}$ のデッキブレートにグー スアスファルト混合物 $40 \mathrm{~mm}$ と改質 I 型アスファルト 


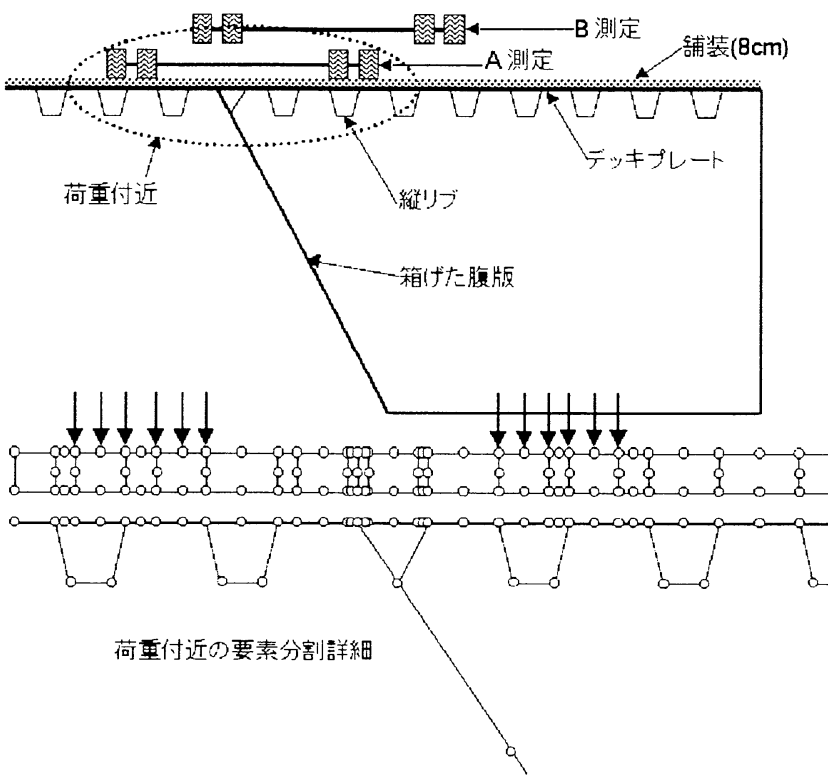

図-7 実橋のおける載荷試験の要素分割
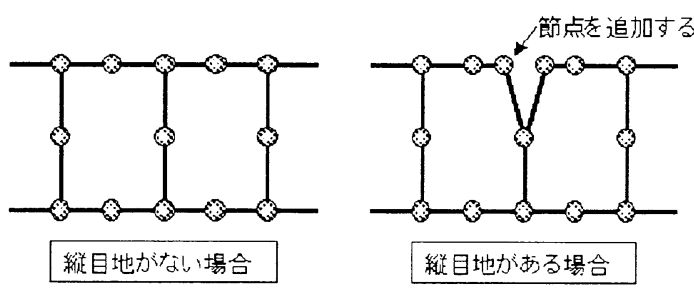

図-8 繸目地のモデル化

表 -3 計算条件

\begin{tabular}{|l|r|r|r|}
\hline \hline 項目 & $\begin{array}{r}\text { アスファ } \\
\text { ルト層 }\end{array}$ & $\begin{array}{r}\text { デッキ } \\
\text { プレート }\end{array}$ & 縦リブ \\
\hline 弹性係数 $[\mathrm{MPa}]$ & 1000,5000 & 208000 & 208000 \\
ボアソン比 & 0.35 & 0.3 & 0.3 \\
厚さ $[\mathrm{mm}]$ & 80 & 12 & 6 \\
\hline \hline
\end{tabular}

混合物 $40 \mathrm{~mm}$ が載った舗装構造であった。横げた間隔 $10 \mathrm{~m}$ のスパン中央部の舗装表面横断方向にひずみゲー ジを貼り付け，大型車トラックの後軸を近づけてひずみ を計測した。この計測は箱げた腹版接合部に縦目地を 設置する前後で実施し, 縦目地の効果を確かめた。後 軸中心を緃目地設置位置に合わせた A 測定と, 一方の 複輪の中心を箱桁腹板接合部に合わせた B 測定という 形で載荷を行った. 載荷試験の詳細は文献 8)を参照さ れたい.

\section{(2) 計算モデル}

図-7はこの載荷試験に対する SLPE モデルの要素分 割である．鋼床版については，断面のほぼ半分の片側 車線のみについて帯板要素にて分割した．舗装部分は 1 層として扱い, タイヤが作用する位置に合わせて, 要 素分割を行った. 縦目地は図-8に示すように, 縦目地
設置部に節点を一つ追加し, その部分で隣り合う要素 の 1 部を切り離すことによってモデル化した．材料定 数は表-3に示すとおりである. 特にアスファルト混合 物の変形係数は載荷速度や温度によって变化するので, その值の設定が問題となる. 通常のアスファルト混合物 であれば，荷重載荷時間を 2 秒，混合物温度を $10^{\circ} \mathrm{C}$ と した場合, $1000 \mathrm{MPa}$ 程度である ${ }^{10)}$ 。一方, 最近用いら れている改質系のアスファルト混合物やグースアスファ ルト混合物の場合はそれよりもやや高い11). そこで, アスファルト層の剛性の影響をみるために, $1000 \mathrm{MPa}$ 察よび $5000 \mathrm{MPa}$ の 2 種類を設定した. アスファルト層 とデッキプレートの接着条件はボンドとし, 接着要素 のばね係数の值は例題 2 のP2 と同じとした.

\section{(3) 実験結果との比較}

図-9 は目地設置前における横断面に沿ったアスファ ルト表面のひずみ分布を示している．左の図は後軸の 中心を箱桁腹板接合部に一致させた $\mathrm{A}$ 測定の結果, 右 の図は一っひ複輪の中心它箱析腹板接合部に一致させ たB 測定の結果である．黒丸は横断方向の実測ひずみ， 白丸は橋軸方向の実測ひずみを示している. SLPEによ る計算值は, 横断方向のひずみを実線で, 橋軸方向のひ ずみを破線で表している. 細い線がアスファルト層の 弾性係数を 1000MPa とした結果で, やや太い線はアス ファルト層の弾性係数を $5000 \mathrm{MPa}$ とした結果である.

$\mathrm{A}$ 測定の場合, 実測によれば腹板接合部に大きな横 断方向の引張ひずみが発生している。一方タイヤ直下 においては圧縮ひずみが生じている。計算值はこのよ うな傾向をよく表現している. とくに，アスファルト 層の弾性係数を $5000 \mathrm{MPa}$ とした場合には, 腹板接合部 における実測の值とほぼ一致している。ひずタ分布は, 荷重作用位置付近以外の縦リブ接合部において引張と なっている.

$\mathrm{B}$ 測定の場合には，腹板接合部の引張りひずみは $\mathrm{A}$ 測定の場合ほど大きくはならないが，それでもやや大 きな引張ひずタになっている. また, 後軸中心付近の縦 リブ接合部にやや大きな引張ひずみが観測された．計算 值はこのような傾向を捉えてはいるが，值そのものはア スファルト層の弾性係数に上って大きく異なる. 全体と して, アスファルト層の弾性係数が $5000 \mathrm{MPa}$ の場合の ひずみ量は, アスファルト層の弾性係数が $1000 \mathrm{MPa} の$ 場合の半分程度になっている. 特に $1000 \mathrm{MPa}$ の場合, ひずみ分布は縦リブ接合部で大きく変化する.このよ うに, アスファルト層の弾性係数が小さくなると, 舗 装のひず夕は鋼床版の構造に大きく影響される.

図-10 は目地設置後におけるアスファルト表面のひ ずみ分布を示している. 図中の凡例は先の図と同様で あり, 縦目地の位置を破線で示した. この場合, 縦目地 

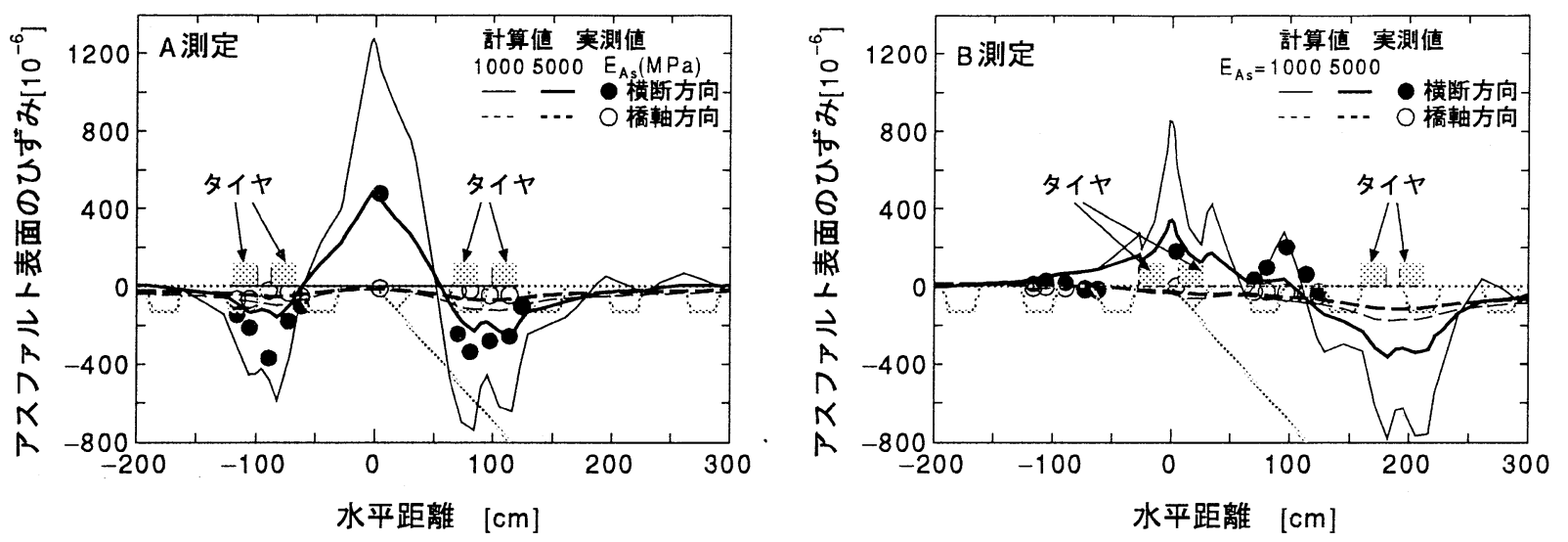

図-9 目地設置前におけるアスファルト表面のひずみ分布
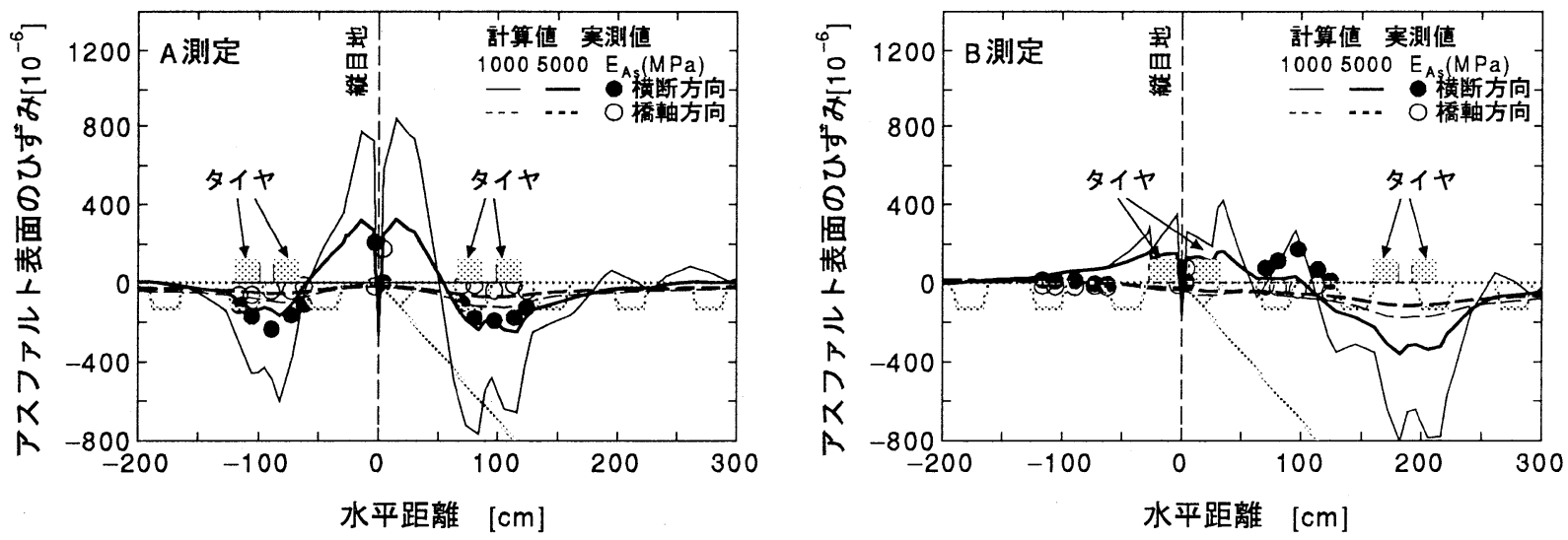

図-10 目地設置後におけるアスファルト層表面のひずみ分布
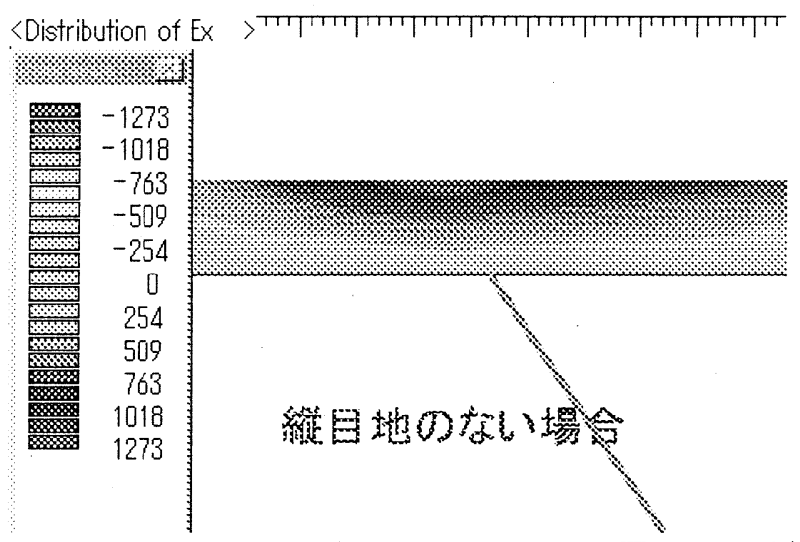

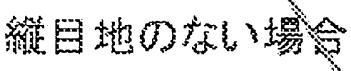
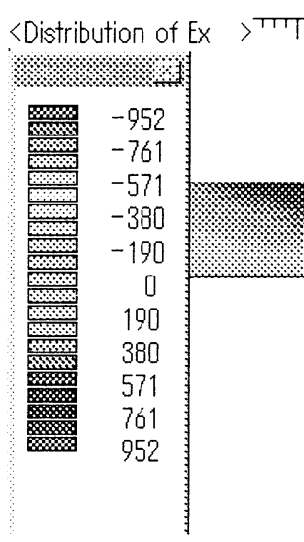

図-11 目地部のひずみ $\left(\epsilon_{x}\right)$ 分布
位置における実測された引張ひずみは大きく減少して いる，計算值は，目地近傍でひずタが激減しているが， それ以外では，目地がない場合とほとんど同じひずみ となっている.すなわち, 目地の効果は目地設置近傍 のきわめて限られた場所のみであって, それ以外の腹 版接合部周辺には，依然として比較的大きな引張ひず みが生じていることになる。この場合も $\mathrm{A}$ 測定におい てはアスファルト層の弾性係数が $5000 \mathrm{MPa}$ の場合の計 算值が実測值と良く一致しており，B 測定の場合には $1000 \mathrm{MPa}$ の計算値に近い.
先に述べたように，SLPE モデルはアスファルト層の 局部的な変形を解析することができる，図-11 は，箱 桁腹板接合部周辺における $\epsilon_{x}$ の分布を示したものであ る. 色が濃いほじ， $\epsilon_{x}$ の值が大きいことを示している. 図から明らかなように，目地がないと $\epsilon_{x}$ の分布は厚さ 方向で引張から圧縮に変化しており，ほぼ一様な曲げ の状態になっているといえる，一方，目地があると，目 地の周辺のひずみが極端に減少するが，ひずタが減少 している領域は非常に小さな範囲に限られていること がわかる。 

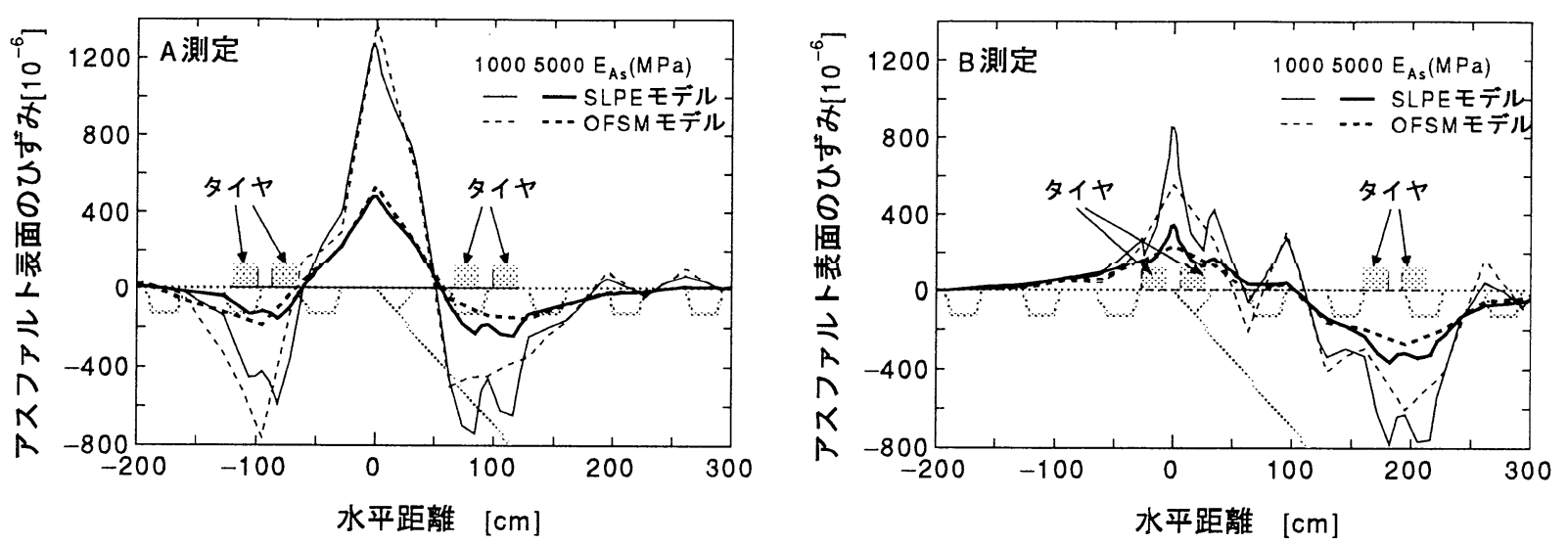

図-12 OFSM モデルとSLPE モデルの比較 (目地設置前, アスファルト表面の横断方向ひずみ)
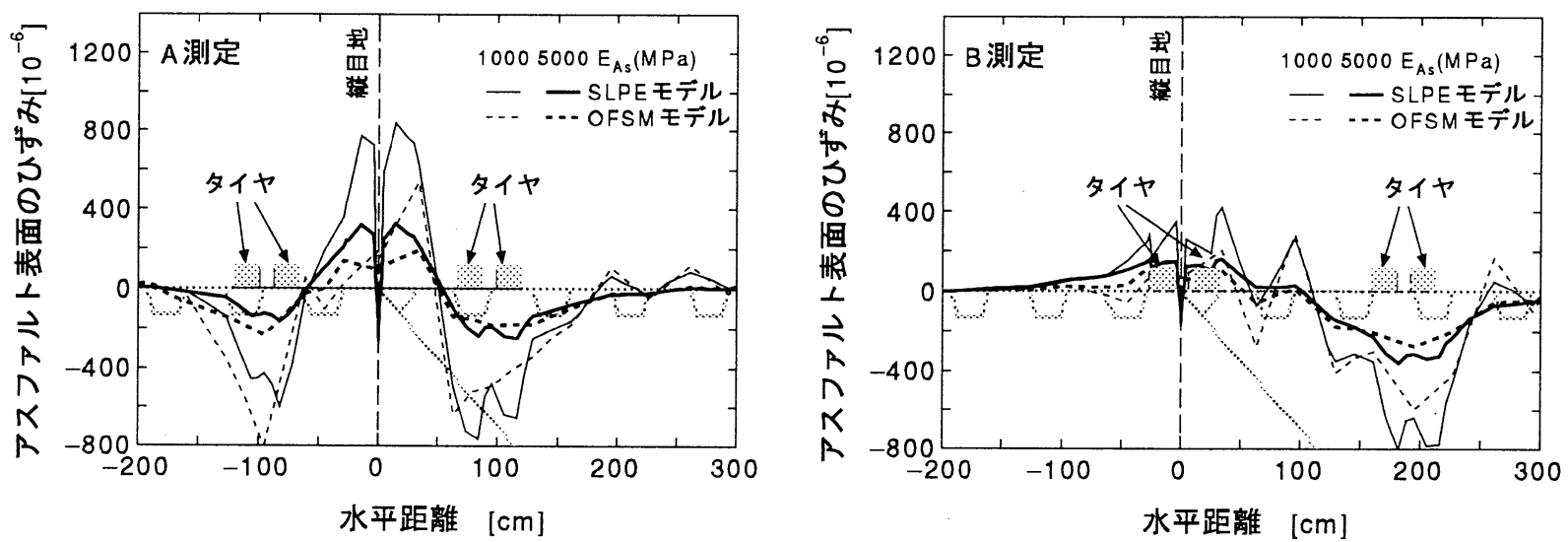

図-13 OFSM モデルと SLPE モデルの比較 (目地設置後, アスファルト表面の横断方向ひずみ)

\section{(4) OFSM モデルとの比較}

SLPE モデルの特性を見るために, OFSM との比較 を行った. 計算モデルは, 載荷試験を行った鋼床版舗装 であり，計算条件はさきほどと同様である，図-12 は 目地設置前の横断方向のひずみ分布を比較した結果で ある、A 測定においては, 腹版接合部のひずタは両モ デルの結果はほぼ同じであるが, タイヤ直下において は, SLPE の計算值はタイヤの間で微妙に変化してい る. B 測定においても, SLPEの計算值はタイヤ間の腹 版接合部の大きなひずみ変化を捉えている.

図-13 は目地設置後のひずみ分布の比較である。目 地設置による目地付近のひずみの減少は, OFSM にお いてやや広い範囲に及ぶが，SLPE ではその効果は非 常に局所的である.したがって, SLPEでは目地設置後 も目地付近に，依然として大きな引張ひずみが計算さ れる.この上うな傾向はB 測定においても同様である.

以上のことから, OFSM に比較して, SLPE は鋼床 版舗装の細かなひずみの変化をよく表現することがで きるということがわかる。

\section{（5）移動荷重}

SLPE モデルによるプログラムにおいては，荷重の $y$ 方向の位置を $y$ 座標值によって与えればよいので, 荷
重の移動を比較的容易に扱うことができる．載荷実験 においては大型車後軸をゲージ位置に近づけながらひ ずみ計測を行っているので，SLPEによってそのような 荷重の移動によるひずみの変化を計算した．図-14は, 荷重の移動による腹版接合部のアスファルト層表面の 横断方向ひずみの変化である. A 測定の場合，荷重の 移動によってもひずみはあまり大きく変化しない。こ れは荷重である後軸の軸間距離が $1.3 \mathrm{~m}$ であるダンデム 軸のため, 荷重が作用する範囲が広いからである。こ の場合, アスファルトの弾性係数を $5000 \mathrm{MPa}$ とすると 実測值と非常に良く合うことがわかる，B 測定の場合， 荷重の移動によるひずみの変化はやや大きく, タイヤ の接近によるピークが見られる．計算值に比べ測定值 はやや小さな值となるが，荷重移動に伴う変化の傾向 は計算值と同じである.

\section{6. あとがき}

本研究においては, 鋼床版舗装の力学的な挙動を, 鋼 床版の構造を含めて解析できる FEM モデルを開発し た. 本モデルは，鋼床版を表現する帯板要素と舗装を表 現する角柱要素を接着要素によって結合したものであ る。帯板要素と角柱要素は自由度が異なるために, 両 

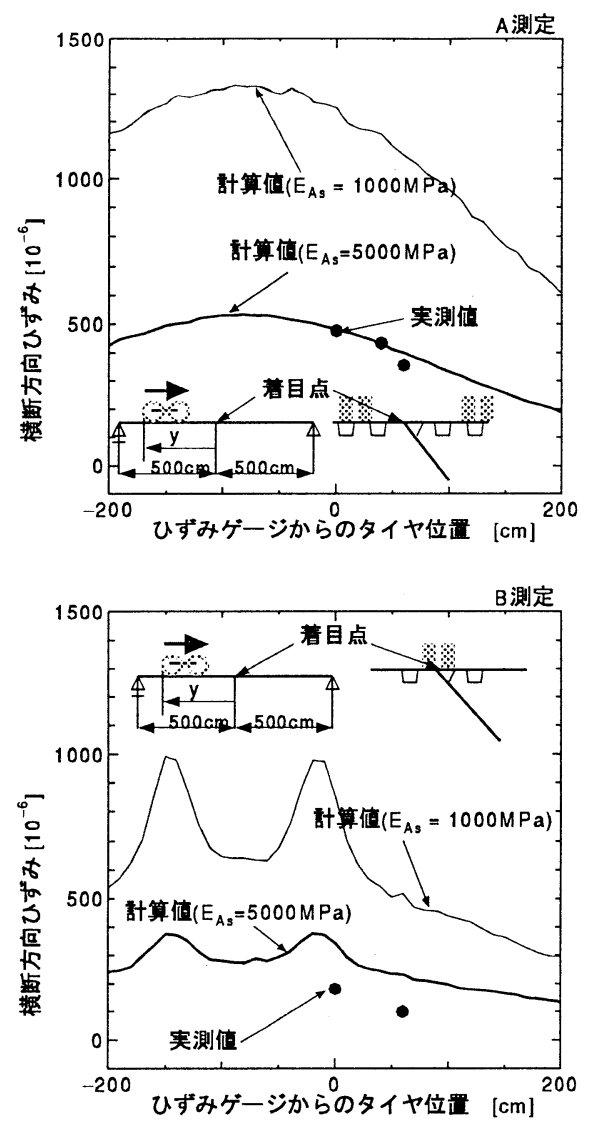

図-14 荷重移動によるひずみの変化

者を結合する接着要素は特殊な要素となる．本モデル に基づいた FEM プログラムを開発し, プログラムの妥 当性を簡単な例題により検証した. さらに, 実橋にお ける載荷実験結果と本モデルによる計算結果との比較 によって，モデルの実用性も確認した. 本モデルの特 徴は以下のとおりである

1. 角柱要素を採用することによって, 舗装内部の細 かなひずみ変化を表現することができる.

2. 特に舗装の剛性が低く, 局所的な変形が生ずる場 合に威力を発揮する.

3. 接着要素のパラメータの与え方によって，デッキ
ブレートと舗装の接着効果を表現できる.

4. 舖装け彩目地を表垷できる。とくに舗装に部分的

にカッタを入れたような目地をモデル化できる.

謝辞 実橋における載荷実験データは, 神奈川県と大 成ロテック株式会社からご提供いただいた。 ここに記 して謝意を表する。

\section{参考文献}

1) 多田宏行 : 橋面舗装と設計施工, 鹿島出版会, 1996.

2) 佐々木道夫: 橋面舗装と鋼床版, アスファルト, Vol. 38, No. 187, pp.44-53, 1996.

3）松川真輔, 吉兼亨, 福永克良：硬化性アスファルトを 用いた鋼床版舗装のひずみ挙動について, 第 15 回日本 道路会議論文集, pp.385-386, 1983.

4) 林秀㑆, 石崎嘉明, 井元泉 : 鋼床版舗装の実橋載荷に よる挙動特性について, 第 20 回日本道路会議論文集, pp.512-513, 1993.

5）角和夫 : 関西国際空港における橋面舗装, アスファル 卜, Vol.38 No.187, pp.29-35, 1997.

6）飯島尚，小島逸平: 鋼床版舗装の疲労曲線，第 15 回日 本道路会議論文集, pp.383-384，1983.

7）岩崎雅紀, 永田考, 西川武宏, 小盐達也, 山田健太郎 : アスファルト舗装が鋼床版の疲労に及ぼす影響, 土木 学会論文集, No.563/I-39, pp.161-171, 1997.

8）西澤辰男，姫野賢治，佐藤亮一，佐藤育正: 銅床版哺装の 構造解析法に関する研究, 土木学会論文集, No.627/V44, pp.103-112, 1999.

9）西澤辰男, 松野三朗 : アスファルト舗装の車輪走行位 置に生ずる縦表面ひび割れについて, 土木学会論文集, No.478/V-21, pp.71-80, 1993.

10）笠原篤，岡川秀幸，菅原照雄 : アスファルト混合物の 動的性状とその舗装構造の力学解析一の利用, 土木学 会論文報告集，第 254 号，pp.107-117，1976.

11）中西弘光：鋼床版舗装への砕石マスチック混合物の適 用について, 舗装, Vol.33, No. 8, pp.4-11, 1998.

12) Cheung, Y.K.: Folded Plate Structures by Finite Strip Method, Proc. of ASCE, Vol. 95, No. ST12, pp.2963-2979, 1969.

13）草間晴幸, 谷山健 : 有限帯板要素法, 日刊工業新聞社, 1994.

14） O.C. ツィエンキーヴィッツ, 吉識雅夫, 山田嘉昭監訳 : マトリックス有限要素法, 培風館, pp.371-378, 1996.

(1999.8.23 受付)

\section{DEVELOPMENT OF A STRUCTURAL MODEL WITH PRISM ELEMENT AND STRIP ELEMENT FOR PAVEMENT ON STEEL PLATE DECK}

\section{Tatsuo NISHIZAWA}

The structural model for pavements on steel plate deck should be able to deal with structure of the steel plate deck as well as pavement structure. This paper presents a structural model using the strip element and prism element. In this model, the steel plate deck is modeled by the strip element and the pavement is divided with the prism element. The strip element and the prism element are connected with a link element. This model is able to analyse the local deformation of pavement, particularly with low stiffness. The validity of the model was verified with numerical examples and comparisons with the experimental results obtained on an actual pavement on a steel plate deck. 